\title{
Circulating Cell Free Tumor DNA Detection as a Routine Tool for Lung Cancer Patient Management
}

\author{
Julie A. Vendrell ${ }^{1}$, Frédéric Tran Mau-Them ${ }^{1}$, Benoît Béganton ${ }^{2,3,4,5}$, Sylvain Godreuil ${ }^{6}$, \\ Peter Coopman ${ }^{2,3,4,5}$ and Jérôme Solassol 1,2,3,5,* \\ 1 CHU Montpellier, Arnaud de Villeneuve Hospital, Department of Pathology, 34295 Montpellier, France; \\ J-vendrell@chu-montpellier.fr (J.A.V.); f-tran_mau_them@chu-montpellier.fr (F.T.M.-T.) \\ 2 IRCM, Institut de Recherche en Cancérologie de Montpellier, 34298 Montpellier, France; \\ benoit.beganton@inserm.fr (B.B.); peter.coopman@inserm.fr (P.C.) \\ 3 INSERM, U1194, 34298 Montpellier, France \\ 4 ICM, Institut Régional du Cancer de Montpellier, 34298 Montpellier, France \\ 5 Université de Montpellier, 34000 Montpellier, France \\ 6 CHU Montpellier, Arnaud de Villeneuve Hospital, Department of Microbiology, 34295 Montpellier, France; \\ S-godreuil@chu-montpellier.fr \\ * Correspondence: j-solassol@chu-montpellier.fr; Tel.: +33-4-6733-5871; Fax: +33-4-6733-9590
}

Academic Editor: William Chi-shing Cho

Received: 29 November 2016; Accepted: 18 January 2017; Published: 29 January 2017

\begin{abstract}
Circulating tumoral DNA (ctDNA), commonly named "liquid biopsy", has emerged as a new promising noninvasive tool to detect biomarker in several cancers including lung cancer. Applications involving molecular analysis of ctDNA in lung cancer have increased and encompass diagnosis, response to treatment, acquired resistance and prognosis prediction, while bypassing the problem of tumor heterogeneity. ctDNA may then help perform dynamic genetic surveillance in the era of precision medicine through indirect tumoral genomic information determination. The aims of this review were to examine the recent technical developments that allowed the detection of genetic alterations of ctDNA in lung cancer. Furthermore, we explored clinical applications in patients with lung cancer including treatment efficiency monitoring, acquired therapy resistance mechanisms and prognosis value.
\end{abstract}

Keywords: circulating DNA; molecular diagnosis; targeted therapies; routine practice; lung cancer

\section{Introduction}

Lung cancer is the most common cause of cancer death around the world. About $80 \%-85 \%$ of lung cancer cases are non-small-cell lung cancer (NSCLC) patients, the remaining 15\%-20\% are small-cell lung cancer (SCLC) [1]. NSCLC is divided into three categories called: adenocarcinoma, squamous-cell adenocarcinoma and large cell adenocarcinoma. Among them, adenocarcinoma cases account for around $40 \%$ of NSCLC patients. The prognosis for NSCLC is low with a five-year survival rate of less than $20 \%$, and is even worse for SCLC with a five-year survival rate of less than $5 \%$ [1].

For a long time, the first-line treatments have been surgery, chemotherapy or radiotherapy. However, the discovery of several oncogenic driver mutations in patients with NSCLC, adenocarcinoma cases in particular, has allowed the development of personalized treatments based on these specific molecular alterations. Therefore, EGFR (epidermal growth factor receptor) mutations account for up to $15 \%$ of adenocarcinoma and primarily occurred in the tyrosine kinase (TK) domain of the gene. More than $80 \%$ of these mutations consist of in-frame deletions in exon 19 and the L858R point mutation in exon 21. Such mutations induced a constitutive activation of EGFR, making it a potential therapeutic target. Thus, EGFR-mutated patients can benefit from a specific first-line treatment 
specifically the TK inhibitors (TKI) that competitively inhibits fixation of adenosine triphosphate (ATP) in the catalytic binding site of TK domain. Other driver biomarkers in lung cancer (point mutations, rearrangements or amplifications in specific genes including KRAS, NRAS, HER2, BRAF, ALK, RET, and ROS1) have also been proposed and some of them might provide additional information for clinical decision-making.

Unfortunately, side effects of personalized treatments have emerged. Among them, the appearance of the T790M mutation located in exon 20 of EGFR systematically results in cancer relapse, generally within 1-2 years. The T790M mutation is present in about half of the lung cancer patients with acquired resistance, and is reported to increase the affinity of the receptor to ATP, relative to its affinity to TKIs [2]. Identification of such mutations is required to propose second-line treatment. Recently, third-generation EGFR inhibitors, such as osimertinib, mereletinib or rociletinib, have been proposed as relevant therapeutics that could specifically disrupt the growth of EGFR T790M-positive tumors and thus increase patient survival [3-5].

\section{Tumor Tissue Biopsy Limitations}

Molecular characterization of tumors became mandatory, not only for patients to receive the right treatment, but also to follow the evolution of the molecular characteristics and, accordingly, to adapt treatments [6]. Tissue biopsies remain the gold standard to assess molecular alterations. However, this strategy presents several limitations that can impair patient treatment. Indeed, access to tumor tissues is not always optimal. Many patients with NSCLC are diagnosed at an advanced stage of the disease that makes the surgery or the biopsy difficult and even sometimes dangerous. Thus, complications from intrathoracic biopsies have been reported in $17.1 \%$ cases in a series of 211 biopsies [7]. In addition, the quality/quantity of the available tumoral material and EGFR genotyping failed in approximately $5 \%$ of the cases [8]. Finally, the intratumoral heterogeneity of $E G F R$ mutation status has been described in several studies (ranges from $13.9 \%$ to $27 \%$; [9]) demonstrating that tumor biopsy do not systematically reveal the complete genomic landscape of the whole patient tumoral cell population. Altogether, these issues related to tissue biopsy analysis failure resulted in an unknown EGFR status and excluded some patients that could have been eligible to TKI treatment.

Given these limitations, exploring alternative practical, economical and less invasive techniques to monitor the EGFR TKI therapy in NSCLC is absolutely needed. Noninvasive approaches, based on samples of plasma or serum, have shown great potential in monitoring the EGFR TKI therapy in recent years. Among the different materials derived from liquid biopsies, ctDNA has been successfully applied to detect EGFR mutations in NSCLC patients and can give similar molecular information as those given by invasive tumor biopsies [10] (Figure 1). In addition, the dynamic changes in ctDNA EGFR mutation status may predict clinical outcome of EGFR TKI therapy [11]. In patient drug resistance instances, one alternative to improve early detection rate and overcome the limitation of repeated tissue sampling is to perform genomic analysis using other liquid biopsy markers such as circulating tumor cells (CTCs), circulating RNA, circulating miRNA, platelet markers, etc. Since the use of these different markers for lung cancer management has previously been reported, it will not be discussed here [11-17].

Hereby, we summarized different technical approaches available that have been proposed for the detection of molecular events from ctDNA and considered their possible applications in hospitals and routine laboratories for the management and monitoring of patients with lung cancer. 


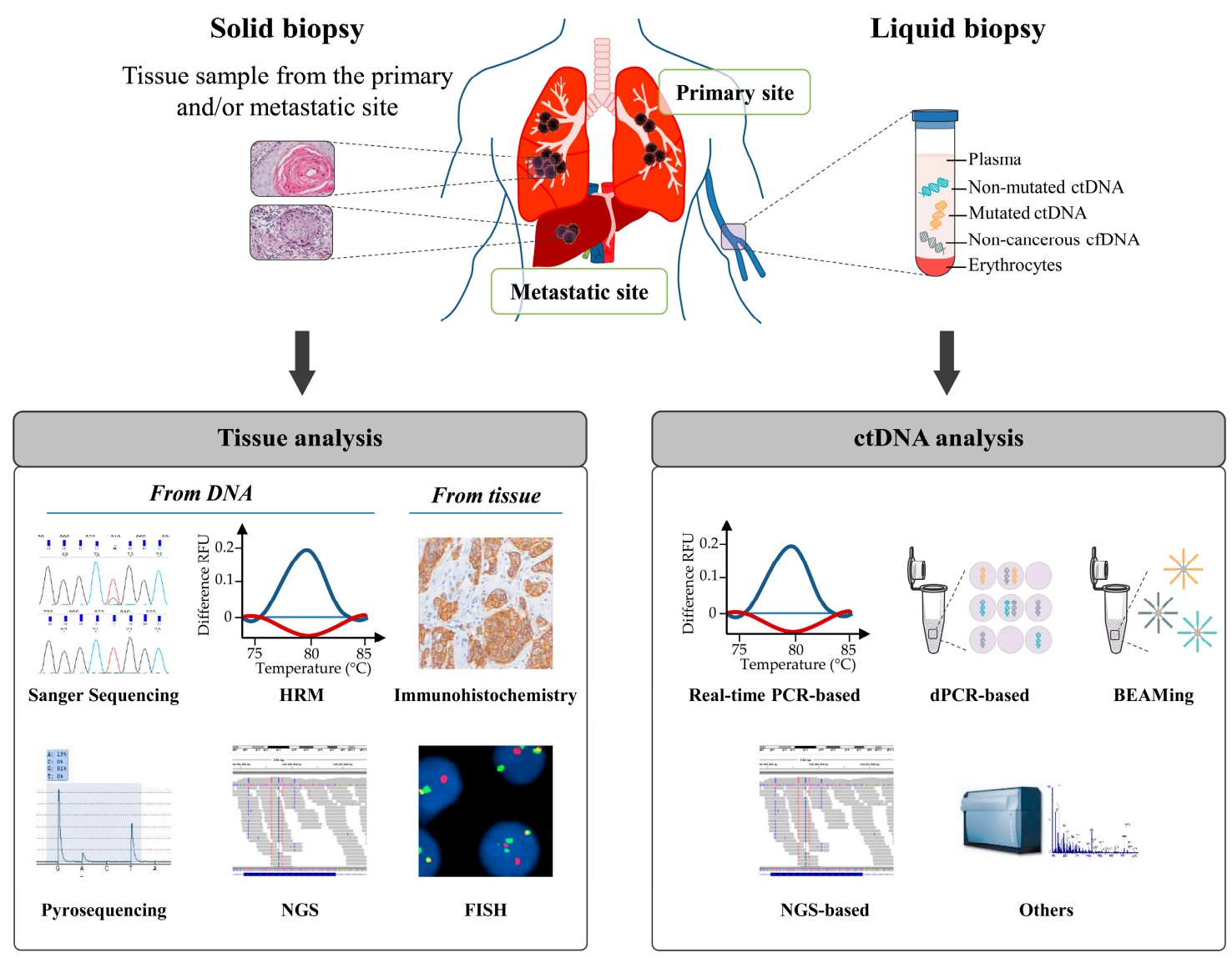

Figure 1. Overview of the available techniques to detect alterations from solid or liquid biopsies. The left side describes the conventional techniques that use tissue sample as starting material, specifically Sanger sequencing, pyrosequencing, High Resolution Melting (HRM), Next-Generation Sequencing (NGS) and Immunohistochemistry. The right side highlights the different methods available for aberration detections from liquid biopsy. They include, in particular, real-time polymerase chain reaction (PCR)-based methods, digital PCR (dPCR), Beads, Emulsion, Amplification, and Magnetics (BEAMing) and NGS-based methods. DNA strand in blue corresponds to non-mutated circulating tumoral DNA (ctDNA), in orange to mutated ctDNA and in grey to non-cancerous cell-free DNA (cfDNA). For each technique, a representation of the principle or the result is given as illustration.

\section{The Biology of cfDNA and Circulating Tumoral DNA (ctDNA)}

New opportunities arose with the discovery of circulating cell-free DNA (cfDNA) in unaffected individuals [18]. Application includes different fields specifically the non-invasive prenatal diagnosis with the use of cell-free fetal DNA (cffDNA; [19]) and cancer with the use of circulating tumor DNA (ctDNA; [20]).

Origin and mechanisms of cfDNA release in bloodstream are still not completely documented. It is however widely accepted that several conditions such as inflammation, heavy smoking, or pregnancy can induce cfDNA release from cells into the systemic circulation [21-23]. As for patients suffering from heart injury, cfDNA increase over the first $48 \mathrm{~h}$ in emergency intensive care unit predicts fatal outcome [24]. The source of ctDNA is also likely multiple and mainly included cell lysis induced by apoptosis and / or necrosis of primary tumors and metastases [25,26] (Figure 1).

cfDNA and ctDNA are highly fragmented with a median size of 170 base pairs or less, which corresponds to the DNA wrapped around a nucleosome plus a linker fragment $[27,28]$. Several studies have tried to clarify the alleged mechanism of ctDNA (necrosis versus apoptosis) depending on the size of the ctDNA, however, results remain controverted [26,29]. Indeed, Wang et al. [30] 
and Gao et al. [31] reported that ctDNA is longer than normal cfDNA [30,31]. Paradoxically, Diel et al. [27] and Moulière et al. [29] observed a lower size of ctDNA. Most importantly, ctDNA is probably composed of short and long fragments with genetic aberrations specifically carried by the shorter ones. This hypothesis has been recently validated in hepathocellular carcinoma patients [32] and in lung cancer patients [22].

\section{Technical Approaches for ctDNA Detection and Analysis}

Preanalytical conditions may certainly play a crucial role in ctDNA detection. Due to different aspects of ctDNA (high fragmentation, contamination by non-tumoral cfDNA, low amounts and clearance), detection of molecular events from ctDNA materials remains a challenge and requires adapted and ultrasensitive analytical assays. Therefore, specific formaldehyde-free cfDNA collection tubes have recently been commercialized. Such processes not only stabilize but also prevent the release of genomic DNA from nucleated blood cells and reduce the need of immediate plasma preparation. In addition, these tubes allow transport and storage at room temperature and are highly adapted to hospital shipment procedures.

Comparative analysis of ctDNA in plasma and serum have shown that plasma represents the best tool to monitor NSCLC patients in clinical practice [33]. However, ctDNA dilution in patient's cfDNA highly limits liquid biopsy's detection of genetic alteration. Only a few thousands of copy number of cfDNA per milliliter of plasma could be extracted, among which only a small fraction is clinically relevant. Therefore, since genetic alterations that need to be detected from ctDNA are diluted by both the non-tumoral cfDNA and by the non-mutated ctDNA, highly sensitive and specific detection methods are required to provide a relevant ctDNA-based diagnosis. This concern has led to the improvement and the development of several methods of detection such as real-time polymerase chain reaction (PCR), digital PCR (dPCR), Next-Generation Sequencing (NGS), Beads, Emulsion, Amplification, and Magnetics (BEAMing) (Table 1). These methods can be classified into two groups: (i) the targeted approaches that allow detection of specific alterations; and (ii) the untargeted approaches that allow identification of events without a priori, in particular whole-exome sequencing or whole-genome sequencing.

Table 1. Features of techniques used to detect alterations from circulating tumoral DNA (ctDNA).

\begin{tabular}{|c|c|c|c|c|}
\hline Techniques & Limit of Detection & Number of Targets & Type of Alteration Detection & Reference \\
\hline \multicolumn{5}{|l|}{ PCR-based approaches } \\
\hline COLD-PCR & $0.10 \%$ & 1 & SNV, indels & [34] \\
\hline PNA-LNA & $0.10 \%$ & 1 & SNV, indels & [35] \\
\hline Probes improvement & $0.01 \%-0.10 \%$ & 1 & SNV, indels & {$[36,37]$} \\
\hline Digital PCR & $0.01 \%-0.10 \%$ & 1 to 4 & SNV, indels, CNV & [38-40] \\
\hline BEAMing & $0.01 \%$ & 1 to 20 & SNV, indels & {$[41,42]$} \\
\hline \multicolumn{5}{|l|}{ NGS-based approaches } \\
\hline Deep sequencing & $0.02 \%$ & Panel & SNV, indels & [43] \\
\hline Base position-error rate correction & $0.003 \%$ & Panel & SNV, indels & [44] \\
\hline TAm-Seq & $2.00 \%$ & Panel & SNV, indels & [45] \\
\hline CAPP-Seq & $0.02 \%$ & Panel & $\mathrm{SNV}$, indels, $\mathrm{CNV}$, rearrangements & [46] \\
\hline cSMART & $0.01 \%$ & Panel & SNV, indels, rearrangements & {$[47,48]$} \\
\hline Digital sequencing & $0.10 \%$ & Panel & $\mathrm{SNV}$, indels, $\mathrm{CNV}$, rearrangements & [49] \\
\hline Bias-Corrected Targeted NGS & $0.10 \%$ & Panel & $\mathrm{SNV}$, indels, $\mathrm{CNV}$, rearrangements & [50] \\
\hline SERS-nanotags & $0.10 \%$ & 1 to 3 & SNV & [51] \\
\hline UltraSEEK & $0.10 \%$ & 1 to 7 & SNV, indels & [52] \\
\hline \multicolumn{5}{|c|}{$\begin{array}{l}\text { PCR, polymerase chain reaction; COLD-PCR, coamplification at lower denaturation temperature PCR; } \\
\text { PNA-LNA, peptide nuclei acid-locked nucleic acid; BEAMing, beads, emulsion, amplification, and magnetics; } \\
\text { NGS, next-generation sequencing; TAm-Seq, tagged-amplicon deep sequencing; CAPP-Seq, cancer personalized } \\
\text { profiling by deep Sequencing; SERS, surface-enhanced raman spectroscopy; UltraSEEK, high-throughput, } \\
\text { multiplexed, ultrasensitive mutation detection; SNV, single nucleotide variation; CNV, copy number variation. }\end{array}$} \\
\hline
\end{tabular}




\subsection{Real-Time PCR-Based Methods}

Allele-specific amplification combined with real-time PCR are commonly used in clinical setting to detect mutations from formalin-fixed paraffin-embedded (FFPE) tumor tissues. Even commercial kits based on the same principle have been developed and are widely used to detect single nucleotide variation (SNV) or small insertion/deletion (indels) (therascreen kit from Qiagen, Hilden, Germany and cobas ${ }^{\circledR}$ from Roche Diagnostics, Meylan, France). However, as they were not fully adapted to the detection of rare genetic events, specific and more sensitive PCR-based methods have been engineered. Notably, custom-designed coamplification at lower denaturation temperature (COLD-PCR) [53,54] or Peptide Nuclei Acid-Locked Nucleic Acid (PNA-LNA) PCR clamp method $[35,55,56]$ have been successfully applied to lung cancer samples. Briefly, COLD-PCR allows the enrichment of low-abundance mutations from a mixture of wild-type, regardless of whether they are known or unknown mutations. Therefore, lower denaturation temperature used during the PCR helps the amplification of heteroduplex mutant/wild-type sequence [34,57]. This PCR method has been further coupled with HRM, pyrosequencing, or Sequencing analysis of the harbored mutations identification [34].

PNA-LNA PCR clamp protocol takes advantage of the increased stability of PNA and LNA probes to highly bind DNA sequences compared to DNA duplex. In this approach, PNA probes firmly bind to DNA to specifically inhibit the amplification of the wild-type allele and thus, increase the specific detection of the mutant allele in real-time PCR cycling. An improved PNA-LNA PCR clamp method has been used to detect EGFR mutations in plasma samples [56].

Efforts were also focused on the improvement of allele-specific amplification technique. Indeed, probe-blocking methods have been engineered to block amplification of wild-type templates and thus, to increase detection sensitivity of mutant alleles. Therefore, minor groove binder (MGB) blocker oligonucleotide [37] and modified non-extendable primer blocker (NEPB) [36] have been developed and demonstrated the detection of mutation present at $0.1 \%$ in a background of wild-type DNA. Scorpion probes, for which higher sensitivity compared to Taqman probes has been demonstrated, also enable the detection of rare mutations [58-62].

Finally, as there is a tremendous and increased market for the detection of mutation from plasma specimens, new versions of commercial kits have been refined. In particular, the cobas ${ }^{\circledR}$ EGFR Mutation Test v2 has been the first liquid biopsy test to be approved by the Food and Drug Administration (FDA) for the detection of EGFR mutations.

\subsection{Digital $P C R(d P C R)$}

dPCR relies on a real-time PCR, except that DNA templates are partitioned to obtain individual DNA molecule per entities (well, droplet or chamber) that are subsequently amplified by PCR and independently analyzed. Based on the Poisson distribution, it is assumed that small volume reaction compartments must contain 0 or 1 DNA molecules. After end-point PCR quantification of positive compartments, absolute concentration of the target is determined. Several digital PCR platforms are available and based on different process: microfluidic-chamber-based, micro-well chip-based and droplet-based [63]. The most common platforms in clinical laboratories are digital droplet PCR (ddPCR) in which samples are dispersed into thousands of droplets. Droplets containing mutated or non-mutated DNA strand can be discriminated by flow cytometry using fluorescent TaqMan-based probes [63], which allows sensitive detection of mutated ctDNA in a vast background of cfDNA.

Besides high sensitivity estimated at $0.01 \%$ to $0.1 \%$ [38], dPCR also has a relatively easy workflow, which can be implemented in a clinical setting [64]. Moreover, it has also been applied to detection of copy number variations (CNVs) in the blood sample of lung cancer patients [65]. One disadvantage is that APCR only screens for known mutations, even if recent works demonstrated the feasibility of multiplex dPCR to detect EGFR and KRAS mutation in blood samples of cancer patients $[40,66]$. 


\subsection{Beads, Emulsion, Amplification and Magnetics (BEAMing)}

BEAMing is also a targeted approach based on the same principle as the emulsion PCR. Briefly, a first conventional PCR step is performed using primers specific of the targeted sequence that contain known tag sequences. Emulsion PCR of the amplicons is done in presence of tag-coupled magnetic beads that is easily purified. After single-base primer extension or hybridization with fluorescent mutant-specific probes, flow cytometric analysis allows the detection and quantification of mutant versus wild-type alleles [42]. In lung cancer samples, this technique already demonstrated its potency in the detection of EGFR activating mutations and the T790M resistance mutation from plasma DNA samples $[41,67,68]$. Like dPCR methods, BEAMing only allows the screening of known mutations, furthermore it also has a complex workflow and a high cost per sample, making implementation in routine clinical settings less feasible.

\subsection{Next-Generation Sequencing (NGS)-Based Approaches}

NGS is based on the analysis of millions of short sequences from DNA molecules and their comparison to a reference sequence. Multiple applications have been developed and currently used in oncology, such as targeted sequencing and whole-exome or whole-genome sequencing. Currently, NGS demonstrates a high sensitivity and specificity; nevertheless, random error rate of sequencing platforms is between $0.1 \%$ and $1 \%$ depending on the platform used [69], making impossible the detection of rare mutations. According to this observation, protocols have been specifically improved and expanded to detect rare mutations in plasma samples. Despite its great advantage to detect multiple somatic alterations simultaneously, NGS remains an expensive and time-consuming technique. Furthermore, extensive data analysis requires highly experienced bioinformaticians to identify with high confidence relevant mutations. Nevertheless, global approaches provide more accurate mutational spectrum of the tumor than targeted analyses and may also allow detection of copy number alterations and large rearrangements $[46,49,50,70]$.

\subsubsection{Deep-Sequencing Using Classical NGS Protocols}

Since classic NGS experimental protocols are not fully adapted to detect rare mutations, first intents to avoid this problem have been to sequence targeted regions with deep-coverage $(>10,000 \times)[43,71,72]$. Another approach was to improve alteration detections using adapted statistical methods. Thus, determination of the base position-error rate (BPER) from control samples allowed detection of true mutations as low as $0.003 \%$ and $0.001 \%$ for indels after statistical computational [44].

\subsubsection{TAm-Seq}

Tagged-amplicon deep sequencing (TAm-Seq) has been the first sequencing method adapted to detect rare diagnosis mutations in cfDNA [45]. It is a two-step amplification process that uses the Access Array microfluidic system from Fluidigm. A first preamplification step where all primer sets are used to capture the starting molecules present in the template is processed and is then followed by a second amplification step with limited couple of primers in the microchambers of the Access Array. This process, that is only adapted to point mutation and indels, allows the identification of cancer mutations at allele frequencies as low as $2 \%$, with more than $97 \%$ sensitivity and specificity [45].

\subsubsection{Cancer Personalized Profiling by Deep Sequencing (CAPP-Seq)}

More recently, a capture-based NGS ctDNA detection method, the Cancer Personalized Profiling by deep Sequencing (CAPP-Seq), has been developed [46,73]. The crucial step of this protocol is the design of biotinylated "selectors" that are complementary of previously defined recurrent mutated regions. After hybrization of the "selectors" on the regions of interest and purification, amplification is carried on the reduced library [46]. Diverse classes of mutations present in somatic samples, including 
single nucleotide variants, indels, rearrangements, and copy number alterations, may thus be detected depending on the designed "selectors".

In lung cancer, this method could identify mutations in 95\% of NSCLC patients with $96 \%$ specificity for mutant allele fractions down to approximately $0.02 \%$ of tumors [46]. It also has been used to detect resistant mechanism in NSCLC-roceletinib-treated patients such as EGFR L798I and EGFR C797S mutations [74]. However, CAPP-Seq is still expensive for routine laboratories, with an estimated cost of 200-300 USD [73].

\subsubsection{Safe-SeqS}

The Safe-Sequencing System (Safe-SeqS) has been proposed as a new tool to increase the sensitivity of massively parallel sequencing system instruments for rare variants identification. A unique identifier (UID) is assigned to each template DNA molecule. Tagged template molecules are then amplified to create UID families and sequences. Variants are considered real if $\geq 95 \%$ of the PCR fragments with the same UID contain an identical mutation [75]. The advantage of this approach is to limit base misincorporation errors during sequencing steps or basecalling errors, and to allow rare mutation detection on commercially available sequencers. To our knowledge, Safe-SeqS has been applied to plasma samples of metatastic colorectal cancer [76] and to GIST patients [77], but not to lung cancer patients.

\subsubsection{Circulating Single Molecule Amplification and Re-Sequencing Technology (cSMART)}

CSMART is another strategy based on a similar approach that can also reduce errors occurring during library preparation or the sequencing phase. Briefly, unique barcodes are added to the end of DNA molecules, they are then circularized by ligation with an oligonucleotide containing a $4 \mathrm{bp}$ degenerate sequence, and are finally amplified using two pairs of reverse PCR targeting primers strategically designed on each side of the hotspot mutation. For detection and quantitation of the targeted mutations, unique single allelic molecules are counted and mutation levels are defined [47]. This method has been used to detect clinically EGFR mutations in plasma samples from patients with advanced NSCLC [48]. Despite the critical step of inverse PCR primers design, one advantage of this approach is that gene fusion with unknown partner fusion can be identified.

\subsubsection{Digital Sequencing}

In digital sequencing experiments, each strand of a double-stranded cfDNA molecule is individually tagged, allowing custom software to compare the two complementary strands and minimize errors occurring during library preparation or the sequencing phase. The digital sequence libraries are amplified and enriched for target genes using capture probes [49]. This process allows detection of SNV, indels, copy number variations (CNVs) and fusion from ctDNA samples [49,70]. As previously described, the authors considered the per-base noise in their bioinformatical process to improve detection of true variant cells.

\subsubsection{Bias-Corrected Targeted Next-Generation Sequencing}

Recently, Paweletz et al. [50] developed a new method for library preparations that allows the minimizing of the off-target and artifacts. Briefly, multifunctional adaptors that include sequences for single-primer amplification, barcodes for sample identification and tags for sequence identification are used during the tagging step. Small targeting probes ( $\sim 40 \mathrm{bp})$ designed to be adjacent to the region of interest are used to capture the targeted regions. Each probe possesses an additional tail sequence that is complementary to a biotinylated pull-down oligonucleotide. After primer extension, captured fragments are amplified with tailed PCR primers and further sequenced. This process has been successfully used for the detection of SNV, CNV and de novo rearrangement detection in 48 ctDNA samples. 


\subsubsection{Untargeted Sequencing}

Whole exome sequencing (WES) and whole genome sequencing (WGS) allow not only the screening of mutations, but also of rearrangements and of copy number variations, providing a more global genomic profiling of ctDNA aberrations. WES method on cancer patients' plasma has been demonstrated in several studies using hybridization-based exome enrichment technologies [78-81]. Regarding WGS sequencing, Leary and colleagues was the first group to establish genome-wide profiling from plasma samples in completion of the personalized analysis of rearranged ends (PARE) method to allow a better identification of rearranged breakpoints from ctDNA [82]. Another group ran WGS in combination with bisulfite DNA sequencing to simultaneously detect genome-wide hypomethylation and copy number aberrations from hepatocellular carcinoma plasma samples $[83,84]$. These large-scale methods are clinically relevant as they allowed detection of alterations in an unbiased manner; however, they are still very expensive to be carried out for clinical diagnosis.

\subsection{Other Technologies}

Recently, alternative technologies using in particular Raman spectrometer or mass-spectrometry have also been development to detect low mutations from ctDNA. Surface-Enhanced Raman Spectroscopy (SERS) nanotags is based on the generation of amplicons by conventional multiplex-PCR with a barcode at the $5^{\prime}$-end that enables the mutation-dependent specific hybridization of SERS-nanotags and a biotin molecule at the $3^{\prime}$-end that allows the specific enrichment of mutated-amplicons. Following a laser excitation, each SERS-nanotag emits a specific signal that enables an easy and direct detection of multiple mutations at the same time using a Raman spectrometer [51].

UltraSEEK (high-throughput, multiplexed, ultrasensitive mutation detection) is a Mass-spectrometrybased technology that has been designed to address the limited multiplexing ability of conventional PCR approaches [52]. Briefly, a multiplex-PCR is first performed to amplify several genes, biotinylated probes, specific of the targeted mutations, are then used to generate biotinylated-mutated-strand. Matrix-Assisted Laser Desorption/Ionization Time-of-Flight Mass Spectrometry (MALDI-TOF MS) is finally used to detect presence of mutations [52].

Of note, three other approaches have previously been described to detect $E G F R$ mutations in plasma DNA from lung cancer patients, including an enzymatic-based technique [85], mass spectrometry genotyping assay [86] and denaturing high performance liquid chromatography [87]. However, these techniques have not been extensively used in routine laboratories.

\section{5. ctDNA and Lung Clinical Applications}

\section{1. ctDNA at Diagnosis}

Since lung cancer is often diagnosed at an advanced stage of the disease, quantification of cfDNA as an early diagnostic tool for lung cancer aroused great interest. Different studies demonstrated that concentration of cfDNA is higher in advanced grade adenocarcinoma patients than in healthy volunteers [88-93]. However, as ctDNA are not detectable in all patients with NSCLC [46,94], the use of cfDNA quantification method is currently limited for lung cancer diagnosis.

One of the most important potential applications for ctDNA in lung cancer diagnosis is the detection of genetic alterations when tumor tissue is not accessible or tissue biopsy DNA extracted is not amplifiable. Many studies have demonstrated whether genetic variations within ctDNA reflects the tumor tissue mutational landscape (Table 2). Interestingly, although specificity is near $100 \%$ regardless of the technique used, the sensitivity is usually weaker (Table 2) and may depend on the alterations' type. Indeed, EGFR T790M mutation showed a significantly lower detection in plasma compared to other EGFR alterations [67,68,95]. However, EGFR mutational detection in ctDNA remains a relevant alternative when the diagnostic tissue biopsy is not available [96]. 
Table 2. Concordance of alteration detections in ctDNA and tissue specimen in lung cancer.

\begin{tabular}{|c|c|c|c|c|c|c|c|}
\hline \multirow{2}{*}{ Targeted Genes } & \multicolumn{2}{|r|}{ Technical Approach } & \multirow{2}{*}{$\begin{array}{c}\text { Number of } \\
\text { Plasma Samples }\end{array}$} & \multicolumn{3}{|c|}{ Performance } & \multirow{2}{*}{ Reference } \\
\hline & Principle & Method & & Sensitivity (\%) & Specificity (\%) & Concordance (\%) & \\
\hline KRAS & PCR-based & COLD-PCR & 82 & 95.7 & 94.9 & 95.1 & [53] \\
\hline EGFR & PCR-based & PNA-LNA & 30 & 79.2 & 100 & $\sim 80$ & [56] \\
\hline EGFR & PCR-based & Therascreen & 652 & 65.7 & 99.8 & 94.3 & [96] \\
\hline EGFR & PCR-based & PNA-adapted method & 97 & 78.3 & 100 & ND & [97] \\
\hline EGFR & PCR-based & Cobas & 32 & 50 & 69.2 & 60 & [98] \\
\hline EGFR & PCR-based & Cobas & 238 & 75 & 96 & 88 & [99] \\
\hline $\begin{array}{l}\text { EGFR } \\
\text { del19/L858R } \\
\text { T790M }\end{array}$ & PCR-based & Cobas & 110 & $\begin{array}{l}73.3 \\
63.6\end{array}$ & $\begin{array}{l}100 \\
98.4\end{array}$ & $\begin{array}{l}79.8 \\
82.8\end{array}$ & [95] \\
\hline $\begin{array}{c}\text { EGFR } \\
\text { del19 } \\
\text { L858R } \\
\text { T790M }\end{array}$ & PCR-based & Cobas & 38 & $\begin{array}{l}86 \\
90 \\
41\end{array}$ & $\begin{array}{l}100 \\
100 \\
100\end{array}$ & $\begin{array}{l}89 \\
97 \\
57\end{array}$ & [68] \\
\hline $\begin{array}{c}\text { EGFR } \\
\text { del19 } \\
\text { L858R } \\
\text { T790M }\end{array}$ & PCR-based & Therascreen & 38 & $\begin{array}{l}82 \\
78 \\
29\end{array}$ & $\begin{array}{l}100 \\
100 \\
100\end{array}$ & $\begin{array}{l}87 \\
95 \\
48\end{array}$ & [68] \\
\hline EGFR & PCR-based & PCR-restriction fragment length polymorphism & 111 & 35.6 & 95.5 & 71 & [100] \\
\hline KRAS & PCR-based & PCR-restriction fragment length polymorphism & 120 & 77 & 95 & 93 & [101] \\
\hline EML4-ALK rearrangement & PCR-based & Taqman probes & 32 & 21 & 100 & 66 & [102] \\
\hline KRAS & $\mathrm{dPCR}$ & Droplet-based & 64 & 78 & 100 & - & [14] \\
\hline EGFR & $\mathrm{dPCR}$ & Droplet-based & 73 & - & - & 74 & [103] \\
\hline EGFR & $\mathrm{dPCR}$ & Droplet-based & 46 & 66.7 & 100 & 84.8 & [104] \\
\hline $\begin{array}{l}\text { EGFR } \\
\text { L858R } \\
\text { T790M }\end{array}$ & $\mathrm{dPCR}$ & Droplet-based & 38 & $\begin{array}{l}90 \\
71\end{array}$ & $\begin{array}{l}100 \\
83\end{array}$ & $\begin{array}{l}97 \\
74\end{array}$ & [68] \\
\hline EGFR & $\mathrm{dPCR}$ & Microfluidic-chamber-based & 35 & 92 & 100 & - & [105] \\
\hline EGFR & BEAMing & BEAMing & 44 & 72.7 & - & 73 & {$[41]$} \\
\hline
\end{tabular}


Table 2. Cont.

\begin{tabular}{|c|c|c|c|c|c|c|c|}
\hline \multirow{2}{*}{ Targeted Genes } & \multicolumn{2}{|c|}{ Technical Approach } & \multirow{2}{*}{$\begin{array}{c}\text { Number of } \\
\text { Plasma Samples }\end{array}$} & \multicolumn{3}{|c|}{ Performance } & \multirow{2}{*}{ Reference } \\
\hline & Principle & Method & & Sensitivity (\%) & Specificity (\%) & Concordance (\%) & \\
\hline EGFR & BEAMing & BEAMing & \multirow{4}{*}{216} & & & & \multirow{4}{*}{ [67] } \\
\hline del19 & & & & 82.3 & 97.5 & - & \\
\hline L858R & & & & 86.3 & 96.5 & - & \\
\hline $\mathrm{T} 790 \mathrm{M}$ & & & & 70.3 & 69 & - & \\
\hline EGFR & BEAMing & BEAMing & \multirow{4}{*}{38} & & & & \multirow{4}{*}{ [68] } \\
\hline del19 & & & & 93 & 100 & 95 & \\
\hline L858R & & & & 100 & 93 & 95 & \\
\hline $\mathrm{T} 790 \mathrm{M}$ & & & & 71 & 67 & 70 & \\
\hline EGFR, KRAS, BRAF & NGS-based & Deep sequencing & 21 & 100 & 100 & 100 & [43] \\
\hline EGFR, KRAS, BRAF, ERBB2, PIK3CA & NGS-based & Deep sequencing & 68 & 58 & 87 & 68 & [71] \\
\hline EGFR & NGS-based & Deep sequencing & \multirow{3}{*}{288} & & & & \multirow{3}{*}{ [72] } \\
\hline del19 & & & & 50.9 & 98 & - & \\
\hline L858R & & & & 51.9 & 94.1 & - & \\
\hline EGFR & NGS-based & Digital sequencing & 50 & - & - & 97.5 & [70] \\
\hline Panel & NGS-based & Digital sequencing & 165 & 85 & 99.6 & 99.3 & [49] \\
\hline EGFR & NGS-based & CAPP-Seq & 43 & 95 & 100 & 91 & [74] \\
\hline EGFR, fusion & NGS-based & CAPP-Seq & 13 & 85 & 96 & - & [46] \\
\hline EGFR & NGS-based & cSMART & 61 & 71.8 & 70 & 90.5 & [48] \\
\hline KRAS, EGFR & NGS-based & Capture & 31 & - & - & 71 & [94] \\
\hline EGFR, KRAS, PIK3CA, fusion & NGS-based & Capture & 39 & 68.5 & 100 & 78.2 & [106] \\
\hline EGFR, fusion, CNV & NGS-based & Bias-corrected & 48 & 77 & 100 & 86 & [50] \\
\hline EGFR & $\begin{array}{c}\text { Mass } \\
\text { spectrometry }\end{array}$ & MALDI-TOF & 31 & 80 & 52.4 & 61 & [86] \\
\hline EGFR & DHPLC & & 230 & 81.8 & 89.5 & 87 & [87] \\
\hline EGFR & Meta-analysis & & 3110 & 63 & 95.9 & - & [107] \\
\hline
\end{tabular}




\section{2. ctDNA as a Prognostic Marker}

ctDNA in lung cancer patients as the new prognostic and predictive tool has been extensively studied and challenged. Indeed, several studies report that high levels of cfDNA result in shorter overall survival (OS) $[108,109]$, whereas other reports show that increased levels of cfDNA are not associated with OS or progression-free survival (PFS) [88,110]. These contrasting results indicate that cfDNA quantification has a limited prognostic value that can result, to some extent, from differences of plasma processing protocols used in the different studies. In contrast, quantification of EGFR mutations in cfDNA seems to be more relevant. Patients with high circulating EGFR copy number levels have a lower OS and PFS than patients with low EGFR copy number levels in plasma [111]. Furthermore, patients with high levels of EGFR activating mutations in TKI-naive plasma sample.have longer OS and PFS $[103,111]$. Regarding the prognostic value of KRAS mutation levels in the plasma of lung cancer patients, discordances are reported and were recently reviewed by Garzón and colleagues [112]. Whereas some studies show that patients with detectable KRAS mutation have a significantly shorter OS and/or PFS compared to wild-type patients [101,113], no differences between the two groups are reported in a recent study and a meta-analysis [14,114]. Altogether, even if some evidence suggests that EGFR status seems to be a more informative prognostic tool than KRAS in plasma samples, a reliable cut-off still needs to be determined.

\section{3. ctDNA and Lung Cancer Tumor Burden}

Another clinical application of cfDNA levels is that they may reflect the total body disease burden and surpass medical imaging for cancer detection. High cfDNA levels are significantly associated with the number of metastatic sites and tumor volume at diagnosis [46,115]. Despite that, Nygaard and colleagues found no correlation between cfDNA levels and tumoral volumetric parameters assessed by positron emission tomography (PET) scans [108], suggesting that cfDNA do not mirror a simple measurement of tumor burden. These discrepancies may primarily be attributed to differences in the methods employed for extraction and quantification.

Currently, PET scans allow the routine radiologic evaluation of treatment response to early detected signs of local recurrences or metastases. However, medical imaging is not always easily accessible, patients are exposed to ionizing radiations, and the metastases need to have reached a significant volume to be detectable. Sozzi et al. [88] first reported a link between an increase in cfDNA levels and further development of metastases or recurrence in the patients. More recently, EGFR mutation from plasma samples has successfully been assessed for early evaluation of the TKI treatment efficiency corresponding to the early radiologic response evaluated by chest X-rays [116]. Newman et al. [46] reported similar correlation between ctDNA levels and treatment-related imaging changes. Altogether, these studies emphasize the powerful potential of ctDNA in the follow-up of lung cancer patients in order to evaluate earlier relapse or to identify patients with residual disease. Recently, Thompson et al. [70] demonstrated the feasibility of multiple ctDNA mutation detections for lung cancer patient management using NGS.

\section{4. ctDNA in Treatment Efficiency Monitoring}

ctDNA also offers the possibility to detect acquired resistance mechanisms, including the second T790M mutation of EGFR, amplification of MET or HER2, and mutations of PIK3CA or BRAF, for early stage lung cancer patients under first-generation TKI medication [70]. Taniguchi et al. [41] identified the T790M mutation in ctDNA in $43.5 \%$ (10/23) of patients who had progressive disease after EGFR-TKI treatment. Another study also proved that sequencing of plasma DNA could complement current invasive approaches to identify mutations associated with acquired drug resistance in advanced cancers [79]. In this study, EGFR T790M mutation could be detected in plasma during the progression, but not at the initiation of treatment for NSCLC gefitinib-treated patients. More recently, the monitoring of T790M apparition in the ctDNA of the first-generation EGFR-TKI treated patients showed an average 
period of 2.2 months before clinical disease progression [39]. Recently, Oxnard et al. [67] proposed that the T790M ctDNA genotyping should warrant the relevant monitoring of patients treated by osimertinib (AZD9291) prior to undergoing a tumor biopsy.

The specific EGFR C797S mutation was also successfully detected in ctDNA in patients who developed resistance to osimertinib [117]. Interestingly, patients who relapsed under rociletinib, a third-generation EGFR-TKI, harbored other mechanisms of resistance including increase of MET copy number and EGFR L798I mutation [74].

\section{Conclusions and Perspectives}

Although analysis and detection of ctDNA have been asserted many years ago, liquid biopsy has recently emerged as a new potential attractive blood-based biomarker with multiple clinical applications for lung cancer patients including primary molecular diagnosis of tumors, resistant mechanisms monitoring to adapt treatments, and cancer prediction outcomes.

The relatively low sensitivity observed in the different studies reported to date can probably be explained by the lack of consensus in the choice of technical approaches, preferred sample type (serum vs. plasma), storage conditions, detected candidate mutation or suitable detection techniques (Table 2). Therefore, in order to complete the analytic and clinical validations of the sensitivity, specificity and accuracy of such liquid biopsy tests and provide the standardization of all experimental steps, ctDNA-based large-scale studies including internal validation (training and test sets) and external validation should be proposed. Targeted approaches could be taken as references since they certainly have a higher analytic sensitivity than untargeted approaches $[118,119]$.

The use of ctDNA within the scope of clinical trials shows significant benefits and will certainly be more considered in the next years. Ultimately and more specifically the patient will highly benefits from the incorporation of this technology into the standard of care. Whether ctDNA provides a complementary or even an adequate alternative to the gold standard tumor biopsies in the near future remains the subject of many speculations. Current limitations that have been reported in many studies such as reduced sensitivity to detect some mutations in ctDNA compared to tissue biopsies should no longer remain an issue, especially because of the constant improvement in genomic approaches.

Author Contributions: Julie Vendrell, Frédéric Tran Mau-Them, Benoît Béganton and Jérôme Solassol wrote the original paper. Sylvain Godreuil and Peter Coopman reviewed the manuscript and participated in discussions about content. All authors have read and approved the final submitted manuscript.

Conflicts of Interest: The authors declare no conflict of interest.

\section{References}

1. Zappa, C.; Mousa, S.A. Non-small cell lung cancer: Current treatment and future advances. Transl. Lung Cancer Res. 2016, 5, 288-300. [CrossRef] [PubMed]

2. Yun, C.H.; Mengwasser, K.E.; Toms, A.V.; Woo, M.S.; Greulich, H.; Wong, K.K.; Meyerson, M.; Eck, M.J. The T790M mutation in EGFR kinase causes drug resistance by increasing the affinity for ATP. Proc. Natl. Acad. Sci. USA 2008, 105, 2070-2075. [CrossRef] [PubMed]

3. Cross, D.A.; Ashton, S.E.; Ghiorghiu, S.; Eberlein, C.; Nebhan, C.A.; Spitzler, P.J.; Orme, J.P.; Finlay, M.R.; Ward, R.A.; Mellor, M.J.; et al. AZD9291, an irreversible EGFR TKI, overcomes T790M-mediated resistance to EGFR inhibitors in lung cancer. Cancer Discov. 2014, 4, 1046-1061. [CrossRef] [PubMed]

4. Walter, A.O.; Sjin, R.T.; Haringsma, H.J.; Ohashi, K.; Sun, J.; Lee, K.; Dubrovskiy, A.; Labenski, M.; Zhu, Z.; Wang, Z.; et al. Discovery of a mutant-selective covalent inhibitor of EGFR that overcomes T790M-mediated resistance in NSCLC. Cancer Discov. 2013, 3, 1404-1415. [CrossRef] [PubMed]

5. Park, K.; Han, J.Y.; Kim, D.W.; Bazhenova, L.A.; Ou, S.H.; Pang, Y.K.; Hin, H.S.; Juan, O.; Son, J.; Janne, P. 190TiP: ELUXA 1: Phase II study of BI 1482694 (HM61713) in patients (pts) with T790M-positive non-small cell lung cancer (NSCLC) after treatment with an epidermal growth factor receptor tyrosine kinase inhibitor (EGFR TKI). J. Thorac. Oncol. 2016, 11, S139. [CrossRef] 
6. Tan, D.S.; Yom, S.S.; Tsao, M.S.; Pass, H.I.; Kelly, K.; Peled, N.; Yung, R.C.; Wistuba, I.I.; Yatabe, Y.; Unger, M.; et al. The International Association for the Study of Lung Cancer Consensus Statement on Optimizing Management of EGFR Mutation-Positive Non-Small Cell Lung Cancer: Status in 2016. J. Thorac. Oncol. 2016, 11, 946-963. [CrossRef] [PubMed]

7. Overman, M.J.; Modak, J.; Kopetz, S.; Murthy, R.; Yao, J.C.; Hicks, M.E.; Abbruzzese, J.L.; Tam, A.L. Use of research biopsies in clinical trials: Are risks and benefits adequately discussed? J. Clin. Oncol. 2013, 31, 17-22. [CrossRef] [PubMed]

8. Barlesi, F.; Mazieres, J.; Merlio, J.P.; Debieuvre, D.; Mosser, J.; Lena, H.; Ouafik, L.; Besse, B.; Rouquette, I.; Westeel, V.; et al. Routine molecular profiling of patients with advanced non-small-cell lung cancer: Results of a 1-year nationwide programme of the French Cooperative Thoracic Intergroup (IFCT). Lancet 2016, 387, 1415-1426. [CrossRef]

9. Remon, J.; Majem, M. EGFR mutation heterogeneity and mixed response to EGFR tyrosine kinase inhibitors of non small cell lung cancer: A clue to overcoming resistance. Transl. Lung Cancer Res. 2013, 2, 445-448. [PubMed]

10. Diaz, L.A., Jr.; Bardelli, A. Liquid biopsies: Genotyping circulating tumor DNA. J. Clin. Oncol. 2014, 32, 579-586. [CrossRef]

11. Sorber, L.; Zwaenepoel, K.; Deschoolmeester, V.; van Schil, P.E.; van Meerbeeck, J.; Lardon, F.; Rolfo, C.; Pauwels, P. Circulating cell-free nucleic acids and platelets as a liquid biopsy in the provision of personalized therapy for lung cancer patients. Lung Cancer 2016. [CrossRef] [PubMed]

12. Gorges, T.M.; Penkalla, N.; Schalk, T.; Joosse, S.A.; Riethdorf, S.; Tucholski, J.; Lucke, K.; Wikman, H.; Jackson, S.; Brychta, N.; et al. Enumeration and Molecular Characterization of Tumor Cells in Lung Cancer Patients Using a Novel In Vivo Device for Capturing Circulating Tumor Cells. Clin. Cancer Res. 2016, 22, 2197-2206. [CrossRef] [PubMed]

13. Guibert, N.; Pradines, A.; Casanova, A.; Farella, M.; Keller, L.; Soria, J.C.; Favre, G.; Mazieres, J. Detection and Monitoring of the BRAF Mutation in Circulating Tumor Cells and Circulating Tumor DNA in BRAF-Mutated Lung Adenocarcinoma. J. Thorac. Oncol. 2016, 11, e109-e112. [CrossRef] [PubMed]

14. Guibert, N.; Pradines, A.; Farella, M.; Casanova, A.; Gouin, S.; Keller, L.; Favre, G.; Mazieres, J. Monitoring KRAS mutations in circulating DNA and tumor cells using digital droplet PCR during treatment of KRAS-mutated lung adenocarcinoma. Lung Cancer 2016, 100, 1-4. [CrossRef] [PubMed]

15. Ma, Y.; Xu, P.; Mi, Y.; Wang, W.; Pan, X.; Wu, X.; He, Q.; Liu, H.; Tang, W.; An, H. Plasma MiRNA alterations between NSCLC patients harboring Del19 and L858R EGFR mutations. Oncotarget 2016, 7, 54965-54972. [CrossRef] [PubMed]

16. Park, S.M.; Wong, D.J.; Ooi, C.C.; Kurtz, D.M.; Vermesh, O.; Aalipour, A.; Suh, S.; Pian, K.L.; Chabon, J.J.; Lee, S.H.; et al. Molecular profiling of single circulating tumor cells from lung cancer patients. Proc. Natl. Acad. Sci. USA 2016, 113, E8379-E8386. [CrossRef] [PubMed]

17. Zhang, H.; Su, Y.; Xu, F.; Kong, J.; Yu, H.; Qian, B. Circulating microRNAs in relation to EGFR status and survival of lung adenocarcinoma in female non-smokers. PLoS ONE 2013, 8, e81408. [CrossRef] [PubMed]

18. Mandel, P.; Metais, P. Les acides nucléiques du plasma sanguin chez l'homme. 1948, 142, 241-243. [PubMed]

19. Lo, Y. M.; Corbetta, N.; Chamberlain, P.F.; Rai, V.; Sargent, I.L.; Redman, C.W.; Wainscoat, J.S. Presence of fetal DNA in maternal plasma and serum. Lancet 1997, 350, 485-487. [CrossRef]

20. Leon, S. Free DNA in the Serum of Cancer Patients and the Effect of Therapy. Cancer Res. 1977, 37, 646-650. [PubMed]

21. Anker, P.; Lyautey, J.; Lederrey, C.; Stroun, M. Circulating nucleic acids in plasma or serum. Clin. Chim. Acta 2001, 313, 143-146. [CrossRef]

22. Underhill, H.R.; Kitzman, J.O.; Hellwig, S.; Welker, N.C.; Daza, R.; Baker, D.N.; Gligorich, K.M.; Rostomily, R.C.; Bronner, M.P.; Shendure, J. Fragment Length of Circulating Tumor DNA. PLoS Genet. 2016, 12, e1006162. [CrossRef] [PubMed]

23. Wei, Z.; Shah, N.; Deng, C.; Xiao, X.; Zhong, T.; Li, X. Circulating DNA addresses cancer monitoring in non small cell lung cancer patients for detection and capturing the dynamic changes of the disease. Springerplus 2016, 5, 531. [CrossRef] [PubMed]

24. Xia, D.L.; Zhang, H.; Luo, Q.L.; Zhang, A.F.; Zhu, L.X. Cell-free DNA increase over first 48 hours in emergency intensive care unit predicts fatal outcome in patients with shock. J. Int. Med. Res. 2016, 44, 1002-1012. [CrossRef] [PubMed] 
25. Bettegowda, C.; Sausen, M.; Leary, R.J.; Kinde, I.; Wang, Y.; Agrawal, N.; Bartlett, B.R.; Wang, H.; Luber, B.; Alani, R.M.; et al. Detection of circulating tumor DNA in early- and late-stage human malignancies. Sci. Transl. Med. 2014, 6, 224ra24. [CrossRef] [PubMed]

26. Cheng, F.; Su, L.; Qian, C. Circulating tumor DNA: A promising biomarker in the liquid biopsy of cancer. Oncotarget 2016, 7, 48832-48841. [CrossRef] [PubMed]

27. Diehl, F.; Li, M.; Dressman, D.; He, Y.; Shen, D.; Szabo, S.; Diaz, L.A., Jr.; Goodman, S.N.; David, K.A.; Juhl, H.; et al. Detection and quantification of mutations in the plasma of patients with colorectal tumors. Proc. Natl. Acad. Sci. USA 2005, 102, 16368-16373. [CrossRef] [PubMed]

28. Lo, Y.M.; Chan, K.C.; Sun, H.; Chen, E.Z.; Jiang, P.; Lun, F.M.; Zheng, Y.W.; Leung, T.Y.; Lau, T.K.; Cantor, C.R.; et al. Maternal plasma DNA sequencing reveals the genome-wide genetic and mutational profile of the fetus. Sci. Transl. Med. 2010, 2, 61ra91. [CrossRef] [PubMed]

29. Mouliere, F.; Robert, B.; Arnau Peyrotte, E.; del Rio, M.; Ychou, M.; Molina, F.; Gongora, C.; Thierry, A.R. High fragmentation characterizes tumour-derived circulating DNA. PLoS ONE 2011, 6, e23418. [CrossRef] [PubMed]

30. Wang, B.G.; Huang, H.Y.; Chen, Y.C.; Bristow, R.E.; Kassauei, K.; Cheng, C.C.; Roden, R.; Sokoll, L.J.; Chan, D.W.; Shih Ie, M. Increased plasma DNA integrity in cancer patients. Cancer Res. 2003, 63, 3966-3968. [PubMed]

31. Gao, Y.J.; He, Y.J.; Yang, Z.L.; Shao, H.Y.; Zuo, Y.; Bai, Y.; Chen, H.; Chen, X.C.; Qin, F.X.; Tan, S.; et al. Increased integrity of circulating cell-free DNA in plasma of patients with acute leukemia. Clin. Chem. Lab. Med. 2010, 48, 1651-1656. [CrossRef] [PubMed]

32. Jiang, P.; Chan, C.W.; Chan, K.C.; Cheng, S.H.; Wong, J.; Wong, V.W.; Wong, G.L.; Chan, S.L.; Mok, T.S.; Chan, H.L.; et al. Lengthening and shortening of plasma DNA in hepatocellular carcinoma patients. Proc. Natl. Acad. Sci. USA 2015, 112, E1317-E1325. [CrossRef] [PubMed]

33. Molina-Vila, M.A.; de-Las-Casas, C.M.; Bertran-Alamillo, J.; Jordana-Ariza, N.; Gonzalez-Cao, M.; Rosell, R. cfDNA analysis from blood in melanoma. Ann. Transl. Med. 2015, 3, 309. [PubMed]

34. Li, J.; Wang, L.; Mamon, H.; Kulke, M.H.; Berbeco, R.; Makrigiorgos, G.M. Replacing PCR with COLD-PCR enriches variant DNA sequences and redefines the sensitivity of genetic testing. Nat. Med. 2008, 14, 579-584. [CrossRef] [PubMed]

35. Nagai, Y.; Miyazawa, H.; Tanaka, T.; Udagawa, K.; Kato, M.; Fukuyama, S.; Yokote, A.; Kobayashi, K.; Kanazawa, M.; Hagiwara, K. Genetic heterogeneity of the epidermal growth factor receptor in non-small cell lung cancer cell lines revealed by a rapid and sensitive detection system, the peptide nucleic acid-locked nucleic acid PCR clamp. Cancer Res. 2005, 65, 7276-7282. [CrossRef] [PubMed]

36. Wang, H.; Jiang, J.; Mostert, B.; Sieuwerts, A.; Martens, J.W.; Sleijfer, S.; Foekens, J.A.; Wang, Y. Allele-specific, non-extendable primer blocker PCR (AS-NEPB-PCR) for DNA mutation detection in cancer. J. Mol. Diagn. 2013, 15, 62-69. [CrossRef] [PubMed]

37. Xie, F.; Huang, J.; Qu, S.; Wu, W.; Jiang, J.; Wang, H.; Wang, S.; Liu, Q.; Zhang, S.; Xu, L.; et al. Sensitive detection of trace amounts of KRAS codon 12 mutations by a fast and novel one-step technique. Clin. Biochem. 2014, 47, 237-242. [CrossRef] [PubMed]

38. Zhang, B.O.; Xu, C.W.; Shao, Y.; Wang, H.T.; Wu, Y.F.; Song, Y.Y.; Li, X.B.; Zhang, Z.; Wang, W.J.; Li, L.Q.; et al. Comparison of droplet digital PCR and conventional quantitative PCR for measuring EGFR gene mutation. Exp. Ther. Med. 2015, 9, 1383-1388. [CrossRef] [PubMed]

39. Zheng, D.; Ye, X.; Zhang, M.Z.; Sun, Y.; Wang, J.Y.; Ni, J.; Zhang, H.P.; Zhang, L.; Luo, J.; Zhang, J.; et al. Plasma EGFR T790M ctDNA status is associated with clinical outcome in advanced NSCLC patients with acquired EGFR-TKI resistance. Sci. Rep. 2016, 6, 20913. [CrossRef] [PubMed]

40. Zonta, E.; Garlan, F.; Pecuchet, N.; Perez-Toralla, K.; Caen, O.; Milbury, C.; Didelot, A.; Fabre, E.; Blons, H.; Laurent-Puig, P.; et al. Multiplex Detection of Rare Mutations by Picoliter Droplet Based Digital PCR: Sensitivity and Specificity Considerations. PLoS ONE 2016, 11, e0159094. [CrossRef] [PubMed]

41. Taniguchi, K.; Uchida, J.; Nishino, K.; Kumagai, T.; Okuyama, T.; Okami, J.; Higashiyama, M.; Kodama, K.; Imamura, F.; Kato, K. Quantitative detection of EGFR mutations in circulating tumor DNA derived from lung adenocarcinomas. Clin. Cancer Res. 2011, 17, 7808-7815. [CrossRef] [PubMed]

42. Diehl, F.; Schmidt, K.; Choti, M.A.; Romans, K.; Goodman, S.; Li, M.; Thornton, K.; Agrawal, N.; Sokoll, L.; Szabo, S.A.; et al. Circulating mutant DNA to assess tumor dynamics. Nat. Med. 2008, 14, 985-990. [CrossRef] [PubMed] 
43. Narayan, A.; Carriero, N.J.; Gettinger, S.N.; Kluytenaar, J.; Kozak, K.R.; Yock, T.I.; Muscato, N.E.; Ugarelli, P.; Decker, R.H.; Patel, A.A. Ultrasensitive measurement of hotspot mutations in tumor DNA in blood using error-suppressed multiplexed deep sequencing. Cancer Res. 2012, 72, 3492-3498. [CrossRef] [PubMed]

44. Pecuchet, N.; Rozenholc, Y.; Zonta, E.; Pietraz, D.; Didelot, A.; Combe, P.; Gibault, L.; Bachet, J.B.; Taly, V.; Fabre, E.; et al. Analysis of Base-Position Error Rate of Next-Generation Sequencing to Detect Tumor Mutations in Circulating DNA. Clin. Chem. 2016, 62, 1492-1503. [CrossRef] [PubMed]

45. Forshew, T.; Murtaza, M.; Parkinson, C.; Gale, D.; Tsui, D.W.; Kaper, F.; Dawson, S.J.; Piskorz, A.M.; Jimenez-Linan, M.; Bentley, D.; et al. Noninvasive identification and monitoring of cancer mutations by targeted deep sequencing of plasma DNA. Sci. Transl. Med. 2012, 4, 136ra68. [CrossRef] [PubMed]

46. Newman, A.M.; Bratman, S.V.; To, J.; Wynne, J.F.; Eclov, N.C.; Modlin, L.A.; Liu, C.L.; Neal, J.W.; Wakelee, H.A.; Merritt, R.E.; et al. An ultrasensitive method for quantitating circulating tumor DNA with broad patient coverage. Nat. Med. 2014, 20, 548-554. [CrossRef] [PubMed]

47. Lv, W.; Wei, X.; Guo, R.; Liu, Q.; Zheng, Y.; Chang, J.; Bai, T.; Li, H.; Zhang, J.; Song, Z.; et al. Noninvasive prenatal testing for Wilson disease by use of circulating single-molecule amplification and resequencing technology (cSMART). Clin. Chem. 2015, 61, 172-181. [CrossRef] [PubMed]

48. Chai, X.; Ren, P.; Wei, B.; Ma, J.; Mai, L.; Cram, D.S.; Song, Y.; Guo, Y. A comparative study of EGFR oncogenic mutations in matching tissue and plasma samples from patients with advanced non-small cell lung carcinoma. Clin. Chim. Acta 2016, 457, 106-111. [CrossRef] [PubMed]

49. Lanman, R.B.; Mortimer, S.A.; Zill, O.A.; Sebisanovic, D.; Lopez, R.; Blau, S.; Collisson, E.A.; Divers, S.G.; Hoon, D.S.; Kopetz, E.S.; et al. Analytical and Clinical Validation of a Digital Sequencing Panel for Quantitative, Highly Accurate Evaluation of Cell-Free Circulating Tumor DNA. PLoS ONE 2015, 10, e0140712. [CrossRef] [PubMed]

50. Paweletz, C.P.; Sacher, A.G.; Raymond, C.K.; Alden, R.S.; O'Connell, A.; Mach, S.L.; Kuang, Y.; Gandhi, L.; Kirschmeier, P.; English, J.M.; et al. Bias-Corrected Targeted Next-Generation Sequencing for Rapid, Multiplexed Detection of Actionable Alterations in Cell-Free DNA from Advanced Lung Cancer Patients. Clin. Cancer Res. 2016, 22, 915-922. [CrossRef] [PubMed]

51. Wee, E.J.; Wang, Y.; Tsao, S.C.; Trau, M. Simple, Sensitive and Accurate Multiplex Detection of Clinically Important Melanoma DNA Mutations in Circulating Tumour DNA with SERS Nanotags. Theranostics 2016, 6, 1506-1513. [CrossRef] [PubMed]

52. Mosko, M.J.; Nakorchevsky, A.A.; Flores, E.; Metzler, H.; Ehrich, M.; van den Boom, D.J.; Sherwood, J.L.; Nygren, A.O. Ultrasensitive Detection of Multiplexed Somatic Mutations Using MALDI-TOF Mass Spectrometry. J. Mol. Diagn. 2016, 18, 23-31. [CrossRef] [PubMed]

53. Freidin, M.B.; Freydina, D.V.; Leung, M.; Montero Fernandez, A.; Nicholson, A.G.; Lim, E. Circulating tumor DNA outperforms circulating tumor cells for KRAS mutation detection in thoracic malignancies. Clin. Chem. 2015, 61, 1299-1304. [CrossRef] [PubMed]

54. Castellanos-Rizaldos, E.; Liu, P.; Milbury, C.A.; Guha, M.; Brisci, A.; Cremonesi, L.; Ferrari, M.; Mamon, H.; Makrigiorgos, G.M. Temperature-tolerant COLD-PCR reduces temperature stringency and enables robust mutation enrichment. Clin. Chem. 2012, 58, 1130-1138. [CrossRef] [PubMed]

55. Miyazawa, H.; Tanaka, T.; Nagai, Y.; Matsuoka, M.; Sutani, A.; Udagawa, K.; Zhang, J.; Hirama, T.; Murayama, Y.; Koyama, N.; et al. Peptide nucleic acid-locked nucleic acid polymerase chain reaction clamp-based detection test for gefitinib-refractory T790M epidermal growth factor receptor mutation. Cancer Sci. 2008, 99, 595-600. [CrossRef] [PubMed]

56. Watanabe, K.; Fukuhara, T.; Tsukita, Y.; Morita, M.; Suzuki, A.; Tanaka, N.; Terasaki, H.; Nukiwa, T.; Maemondo, M. EGFR Mutation Analysis of Circulating Tumor DNA Using an Improved PNA-LNA PCR Clamp Method. Can. Respir. J. 2016, 2016, 5297329. [CrossRef] [PubMed]

57. Li, J.; Makrigiorgos, G.M. COLD-PCR: A new platform for highly improved mutation detection in cancer and genetic testing. Biochem. Soc. Trans. 2009, 37, 427-432. [CrossRef] [PubMed]

58. Board, R.E.; Wardley, A.M.; Dixon, J.M.; Armstrong, A.C.; Howell, S.; Renshaw, L.; Donald, E.; Greystoke, A.; Ranson, M.; Hughes, A.; et al. Detection of PIK3CA mutations in circulating free DNA in patients with breast cancer. Breast Cancer Res. Treat. 2010, 120, 461-467. [CrossRef] [PubMed]

59. Wang, S.; Han, X.; Hu, X.; Wang, X.; Zhao, L.; Tang, L.; Feng, Y.; Wu, D.; Sun, Y.; Shi, Y. Clinical significance of pretreatment plasma biomarkers in advanced non-small cell lung cancer patients. Clin. Chim. Acta 2014, 430, 63-70. [CrossRef] [PubMed] 
60. Goto, K.; Ichinose, Y.; Ohe, Y.; Yamamoto, N.; Negoro, S.; Nishio, K.; Itoh, Y.; Jiang, H.; Duffield, E.; McCormack, R.; et al. Epidermal growth factor receptor mutation status in circulating free DNA in serum: From IPASS, a phase III study of gefitinib or carboplatin/paclitaxel in non-small cell lung cancer. J. Thorac. Oncol. 2012, 7, 115-121. [CrossRef] [PubMed]

61. Kimura, H.; Suminoe, M.; Kasahara, K.; Sone, T.; Araya, T.; Tamori, S.; Koizumi, F.; Nishio, K.; Miyamoto, K.; Fujimura, M.; et al. Evaluation of epidermal growth factor receptor mutation status in serum DNA as a predictor of response to gefitinib (IRESSA). Br. J. Cancer 2007, 97, 778-784. [CrossRef] [PubMed]

62. Kimura, H.; Kasahara, K.; Kawaishi, M.; Kunitoh, H.; Tamura, T.; Holloway, B.; Nishio, K. Detection of epidermal growth factor receptor mutations in serum as a predictor of the response to gefitinib in patients with non-small-cell lung cancer. Clin. Cancer Res. 2006, 12, 3915-3921. [CrossRef] [PubMed]

63. Dong, L.; Meng, Y.; Sui, Z.; Wang, J.; Wu, L.; Fu, B. Comparison of four digital PCR platforms for accurate quantification of DNA copy number of a certified plasmid DNA reference material. Sci. Rep. 2015, 5, 13174. [CrossRef] [PubMed]

64. Malapelle, U.; de Luca, C.; Vigliar, E.; Ambrosio, F.; Rocco, D.; Pisapia, P.; Bellevicine, C.; Troncone, G. EGFR mutation detection on routine cytological smears of non-small cell lung cancer by digital PCR: A validation study. J. Clin. Pathol. 2016, 69, 454-457. [CrossRef] [PubMed]

65. Shoda, K.; Ichikawa, D.; Fujita, Y.; Masuda, K.; Hiramoto, H.; Hamada, J.; Arita, T.; Konishi, H.; Komatsu, S.; Shiozaki, A.; et al. Monitoring the HER2 copy number status in circulating tumor DNA by droplet digital PCR in patients with gastric cancer. Gastric Cancer 2017, 20, 126-135. [CrossRef] [PubMed]

66. Taly, V.; Pekin, D.; Benhaim, L.; Kotsopoulos, S.K.; le Corre, D.; Li, X.; Atochin, I.; Link, D.R.; Griffiths, A.D.; Pallier, K.; et al. Multiplex picodroplet digital PCR to detect KRAS mutations in circulating DNA from the plasma of colorectal cancer patients. Clin. Chem. 2013, 59, 1722-1731. [CrossRef] [PubMed]

67. Oxnard, G.R.; Thress, K.S.; Alden, R.S.; Lawrance, R.; Paweletz, C.P.; Cantarini, M.; Yang, J.C.; Barrett, J.C.; Janne, P.A. Association Between Plasma Genotyping and Outcomes of Treatment with Osimertinib (AZD9291) in Advanced Non-Small-Cell Lung Cancer. J. Clin. Oncol. 2016, 34, 3375-3382. [CrossRef] [PubMed]

68. Thress, K.S.; Brant, R.; Carr, T.H.; Dearden, S.; Jenkins, S.; Brown, H.; Hammett, T.; Cantarini, M.; Barrett, J.C. EGFR mutation detection in ctDNA from NSCLC patient plasma: A cross-platform comparison of leading technologies to support the clinical development of AZD9291. Lung Cancer 2015, 90, 509-515. [CrossRef] [PubMed]

69. Quail, M.A.; Smith, M.; Coupland, P.; Otto, T.D.; Harris, S.R.; Connor, T.R.; Bertoni, A.; Swerdlow, H.P.; Gu, Y. A tale of three next generation sequencing platforms: Comparison of Ion Torrent, Pacific Biosciences and Illumina MiSeq sequencers. BMC Genom. 2012, 13, 341. [CrossRef] [PubMed]

70. Thompson, J.C.; Yee, S.S.; Troxel, A.B.; Savitch, S.L.; Fan, R.; Balli, D.; Lieberman, D.B.; Morrissette, J.D.; Evans, T.L.; Bauml, J.; et al. Detection of Therapeutically Targetable Driver and Resistance Mutations in Lung Cancer Patients by Next-Generation Sequencing of Cell-Free Circulating Tumor DNA. Clin. Cancer Res. 2016, 22, 5772-5782. [CrossRef] [PubMed]

71. Couraud, S.; Vaca-Paniagua, F.; Villar, S.; Oliver, J.; Schuster, T.; Blanche, H.; Girard, N.; Tredaniel, J.; Guilleminault, L.; Gervais, R.; et al. Noninvasive diagnosis of actionable mutations by deep sequencing of circulating free DNA in lung cancer from never-smokers: A proof-of-concept study from BioCAST/IFCT-1002. Clin. Cancer Res. 2014, 20, 4613-4624. [CrossRef] [PubMed]

72. Uchida, J.; Kato, K.; Kukita, Y.; Kumagai, T.; Nishino, K.; Daga, H.; Nagatomo, I.; Inoue, T.; Kimura, M.; Oba, S.; et al. Diagnostic Accuracy of Noninvasive Genotyping of EGFR in Lung Cancer Patients by Deep Sequencing of Plasma Cell-Free DNA. Clin. Chem. 2015, 61, 1191-1196. [CrossRef] [PubMed]

73. Bratman, S.V.; Newman, A.M.; Alizadeh, A.A.; Diehn, M. Potential clinical utility of ultrasensitive circulating tumor DNA detection with CAPP-Seq. Expert Rev. Mol. Diagn. 2015, 15, 715-719. [CrossRef] [PubMed]

74. Chabon, J.J.; Simmons, A.D.; Lovejoy, A.F.; Esfahani, M.S.; Newman, A.M.; Haringsma, H.J.; Kurtz, D.M.; Stehr, H.; Scherer, F.; Karlovich, C.A.; et al. Circulating tumour DNA profiling reveals heterogeneity of EGFR inhibitor resistance mechanisms in lung cancer patients. Nat. Commun. 2016, 7, 11815. [CrossRef] [PubMed]

75. Kinde, I.; Wu, J.; Papadopoulos, N.; Kinzler, K.W.; Vogelstein, B. Detection and quantification of rare mutations with massively parallel sequencing. Proc. Natl. Acad. Sci. USA 2011, 108, 9530-9535. [CrossRef] [PubMed] 
76. Tie, J.; Kinde, I.; Wang, Y.; Wong, H.L.; Roebert, J.; Christie, M.; Tacey, M.; Wong, R.; Singh, M.; Karapetis, C.S.; et al. Circulating tumor DNA as an early marker of therapeutic response in patients with metastatic colorectal cancer. Ann. Oncol. 2015, 26, 1715-1722. [CrossRef] [PubMed]

77. Fredebohm, J.; Mehnert, D.H.; Lober, A.K.; Holtrup, F.; van Rahden, V.; Angenendt, P.; Diehl, F. Detection and Quantification of KIT Mutations in ctDNA by Plasma Safe-SeqS. Adv. Exp. Med. Biol. 2016, 924, 187-189. [PubMed]

78. Dietz, S.; Schirmer, U.; Merce, C.; von Bubnoff, N.; Dahl, E.; Meister, M.; Muley, T.; Thomas, M.; Sultmann, H. Low Input Whole-Exome Sequencing to Determine the Representation of the Tumor Exome in Circulating DNA of Non-Small Cell Lung Cancer Patients. PLoS ONE 2016, 11, e0161012. [CrossRef] [PubMed]

79. Murtaza, M.; Dawson, S.J.; Tsui, D.W.; Gale, D.; Forshew, T.; Piskorz, A.M.; Parkinson, C.; Chin, S.F.; Kingsbury, Z.; Wong, A.S.; et al. Non-invasive analysis of acquired resistance to cancer therapy by sequencing of plasma DNA. Nature 2013, 497, 108-112. [CrossRef] [PubMed]

80. Butler, T.M.; Johnson-Camacho, K.; Peto, M.; Wang, N.J.; Macey, T.A.; Korkola, J.E.; Koppie, T.M.; Corless, C.L.; Gray, J.W.; Spellman, P.T. Exome Sequencing of Cell-Free DNA from Metastatic Cancer Patients Identifies Clinically Actionable Mutations Distinct from Primary Disease. PLoS ONE 2015, 10, e0136407. [CrossRef] [PubMed]

81. Klevebring, D.; Neiman, M.; Sundling, S.; Eriksson, L.; Darai Ramqvist, E.; Celebioglu, F.; Czene, K.; Hall, P.; Egevad, L.; Gronberg, H.; et al. Evaluation of exome sequencing to estimate tumor burden in plasma. PLoS ONE 2014, 9, e104417. [CrossRef] [PubMed]

82. Leary, R.J.; Sausen, M.; Kinde, I.; Papadopoulos, N.; Carpten, J.D.; Craig, D.; O'Shaughnessy, J.; Kinzler, K.W.; Parmigiani, G.; Vogelstein, B.; et al. Detection of chromosomal alterations in the circulation of cancer patients with whole-genome sequencing. Sci. Transl. Med. 2012, 4, 162ra154. [CrossRef] [PubMed]

83. Chan, K.C.; Jiang, P.; Chan, C.W.; Sun, K.; Wong, J.; Hui, E.P.; Chan, S.L.; Chan, W.C.; Hui, D.S.; Ng, S.S.; et al. Noninvasive detection of cancer-associated genome-wide hypomethylation and copy number aberrations by plasma DNA bisulfite sequencing. Proc. Natl. Acad. Sci. USA 2013, 110, 18761-18768. [CrossRef] [PubMed]

84. Chan, K.C.; Jiang, P.; Zheng, Y.W.; Liao, G.J.; Sun, H.; Wong, J.; Siu, S.S.; Chan, W.C.; Chan, S.L.; Chan, A.T.; et al. Cancer genome scanning in plasma: Detection of tumor-associated copy number aberrations, single-nucleotide variants, and tumoral heterogeneity by massively parallel sequencing. Clin. Chem. 2013, 59, 211-224. [CrossRef] [PubMed]

85. Kuang, Y.; Rogers, A.; Yeap, B.Y.; Wang, L.; Makrigiorgos, M.; Vetrand, K.; Thiede, S.; Distel, R.J.; Janne, P.A. Noninvasive detection of EGFR T790M in gefitinib or erlotinib resistant non-small cell lung cancer. Clin. Cancer. Res. 2009, 15, 2630-2636. [CrossRef] [PubMed]

86. Brevet, M.; Johnson, M.L.; Azzoli, C.G.; Ladanyi, M. Detection of EGFR mutations in plasma DNA from lung cancer patients by mass spectrometry genotyping is predictive of tumor EGFR status and response to EGFR inhibitors. Lung Cancer 2011, 73, 96-102. [CrossRef] [PubMed]

87. Bai, H.; Mao, L.; Wang, H.S.; Zhao, J.; Yang, L.; An, T.T.; Wang, X.; Duan, C.J.; Wu, N.M.; Guo, Z.Q.; et al. Epidermal growth factor receptor mutations in plasma DNA samples predict tumor response in Chinese patients with stages IIIB to IV non-small-cell lung cancer. J. Clin. Oncol. 2009, 27, 2653-2659. [CrossRef] [PubMed]

88. Sozzi, G.; Conte, D.; Mariani, L.; Lo Vullo, S.; Roz, L.; Lombardo, C.; Pierotti, M.A.; Tavecchio, L. Analysis of circulating tumor DNA in plasma at diagnosis and during follow-up of lung cancer patients. Cancer Res. 2001, 61, 4675-4678. [PubMed]

89. Sozzi, G.; Conte, D.; Leon, M.; Ciricione, R.; Roz, L.; Ratcliffe, C.; Roz, E.; Cirenei, N.; Bellomi, M.; Pelosi, G.; et al. Quantification of free circulating DNA as a diagnostic marker in lung cancer. J. Clin. Oncol. 2003, 21, 3902-3908. [CrossRef] [PubMed]

90. Paci, M.; Maramotti, S.; Bellesia, E.; Formisano, D.; Albertazzi, L.; Ricchetti, T.; Ferrari, G.; Annessi, V.; Lasagni, D.; Carbonelli, C.; et al. Circulating plasma DNA as diagnostic biomarker in non-small cell lung cancer. Lung Cancer 2009, 64, 92-97. [CrossRef] [PubMed]

91. Yoon, K.A.; Park, S.; Lee, S.H.; Kim, J.H.; Lee, J.S. Comparison of circulating plasma DNA levels between lung cancer patients and healthy controls. J. Mol. Diagn. 2009, 11, 182-185. [CrossRef] [PubMed]

92. Szpechcinski, A.; Dancewicz, M.; Kopinski, P.; Kowalewski, J.; Chorostowska-Wynimko, J. Real-time PCR quantification of plasma DNA in non-small cell lung cancer patients and healthy controls. Eur. J. Med. Res. 2009, 14, 237-240. [CrossRef] [PubMed] 
93. Ulivi, P.; Silvestrini, R. Role of quantitative and qualitative characteristics of free circulating DNA in the management of patients with non-small cell lung cancer. Cell Oncol. 2013, 36, 439-448. [CrossRef] [PubMed]

94. Villaflor, V.; Won, B.; Nagy, R.; Banks, K.; Lanman, R.B.; Talasaz, A.; Salgia, R. Biopsy-free circulating tumor DNA assay identifies actionable mutations in lung cancer. Oncotarget 2016, 7, 66880-66891. [CrossRef] [PubMed]

95. Karlovich, C.; Goldman, J.W.; Sun, J.M.; Mann, E.; Sequist, L.V.; Konopa, K.; Wen, W.; Angenendt, P.; Horn, L.; Spigel, D.; et al. Assessment of EGFR Mutation Status in Matched Plasma and Tumor Tissue of NSCLC Patients from a Phase I Study of Rociletinib (CO-1686). Clin. Cancer Res. 2016, 22, 2386-2395. [CrossRef]

96. Douillard, J.Y.; Ostoros, G.; Cobo, M.; Ciuleanu, T.; McCormack, R.; Webster, A.; Milenkova, T. First-line gefitinib in Caucasian EGFR mutation-positive NSCLC patients: A phase-IV, open-label, single-arm study. Br. J. Cancer 2014, 110, 55-62. [CrossRef] [PubMed]

97. Karachaliou, N.; de las Casas, C.M.; Queralt, C.; de Aguirre, I.; Melloni, B.; Cardenal, F.; Garcia-Gomez, R.; Massuti, B.; Sanchez, J.M.; Porta, R.; et al. Association of EGFR L858R Mutation in Circulating Free DNA With Survival in the EURTAC Trial. JAMA Oncol. 2015, 1, 149-157. [CrossRef] [PubMed]

98. Sundaresan, T.K.; Sequist, L.V.; Heymach, J.V.; Riely, G.J.; Janne, P.A.; Koch, W.H.; Sullivan, J.P.; Fox, D.B.; Maher, R.; Muzikansky, A.; et al. Detection of T790M, the Acquired Resistance EGFR Mutation, by Tumor Biopsy versus Noninvasive Blood-Based Analyses. Clin. Cancer Res. 2016, 22, 1103-1110. [CrossRef] [PubMed]

99. Mok, T.; Wu, Y.L.; Lee, J.S.; Yu, C.J.; Sriuranpong, V.; Sandoval-Tan, J.; Ladrera, G.; Thongprasert, S.; Srimuninnimit, V.; Liao, M.; et al. Detection and Dynamic Changes of EGFR Mutations from Circulating Tumor DNA as a Predictor of Survival Outcomes in NSCLC Patients Treated with First-line Intercalated Erlotinib and Chemotherapy. Clin. Cancer Res. 2015, 21, 3196-3203. [CrossRef] [PubMed]

100. Zhao, X.; Han, R.B.; Zhao, J.; Wang, J.; Yang, F.; Zhong, W.; Zhang, L.; Li, L.Y.; Wang, M.Z. Comparison of epidermal growth factor receptor mutation statuses in tissue and plasma in stage I-IV non-small cell lung cancer patients. Respiration 2013, 85, 119-125. [CrossRef] [PubMed]

101. Wang, S.; An, T.; Wang, J.; Zhao, J.; Wang, Z.; Zhuo, M.; Bai, H.; Yang, L.; Zhang, Y.; Wang, X.; et al. Potential clinical significance of a plasma-based KRAS mutation analysis in patients with advanced non-small cell lung cancer. Clin. Cancer Res. 2010, 16, 1324-1330. [CrossRef] [PubMed]

102. Nilsson, R.J.; Karachaliou, N.; Berenguer, J.; Gimenez-Capitan, A.; Schellen, P.; Teixido, C.; Tannous, J.; Kuiper, J.L.; Drees, E.; Grabowska, M.; et al. Rearranged EML4-ALK fusion transcripts sequester in circulating blood platelets and enable blood-based crizotinib response monitoring in non-small-cell lung cancer. Oncotarget 2016, 7, 1066-1075. [CrossRef] [PubMed]

103. Yang, X.; Zhuo, M.; Ye, X.; Bai, H.; Wang, Z.; Sun, Y.; Zhao, J.; An, T.; Duan, J.; Wu, M.; et al. Quantification of mutant alleles in circulating tumor DNA can predict survival in lung cancer. Oncotarget 2016, 7, 20810-20824. [CrossRef] [PubMed]

104. Oxnard, G.R.; Paweletz, C.P.; Kuang, Y.; Mach, S.L.; O'Connell, A.; Messineo, M.M.; Luke, J.J.; Butaney, M.; Kirschmeier, P.; Jackman, D.M.; et al. Noninvasive detection of response and resistance in EGFR-mutant lung cancer using quantitative next-generation genotyping of cell-free plasma DNA. Clin. Cancer Res. 2014, 20, 1698-1705. [CrossRef] [PubMed]

105. Yung, T.K.; Chan, K.C.; Mok, T.S.; Tong, J.; To, K.F.; Lo, Y.M. Single-molecule detection of epidermal growth factor receptor mutations in plasma by microfluidics digital PCR in non-small cell lung cancer patients. Clin. Cancer Res. 2009, 15, 2076-2084. [CrossRef] [PubMed]

106. Yao, Y.; Liu, J.; Li, L.; Yuan, Y.; Nan, K.; Wu, X.; Zhang, Z.; Wu, Y.; Li, X.; Zhu, J.; et al. Detection of circulating tumor DNA in patients with advanced non-small cell lung cancer. Oncotarget 2016. [CrossRef] [PubMed]

107. Qiu, M.; Wang, J.; Xu, Y.; Ding, X.; Li, M.; Jiang, F.; Xu, L.; Yin, R. Circulating tumor DNA is effective for the detection of EGFR mutation in non-small cell lung cancer: A meta-analysis. Cancer Epidemiol. Biomark. Prev. 2015, 24, 206-212. [CrossRef] [PubMed]

108. Nygaard, A.D.; Holdgaard, P.C.; Spindler, K.L.; Pallisgaard, N.; Jakobsen, A. The correlation between cell-free DNA and tumour burden was estimated by PET/CT in patients with advanced NSCLC. Br. J. Cancer 2014, 110, 363-368. [CrossRef] [PubMed]

109. Catarino, R.; Coelho, A.; Araujo, A.; Gomes, M.; Nogueira, A.; Lopes, C.; Medeiros, R. Circulating DNA: Diagnostic tool and predictive marker for overall survival of NSCLC patients. PLoS ONE 2012, 7, e38559. [CrossRef] [PubMed] 
110. Herrera, L.J.; Raja, S.; Gooding, W.E.; El-Hefnawy, T.; Kelly, L.; Luketich, J.D.; Godfrey, T.E. Quantitative analysis of circulating plasma DNA as a tumor marker in thoracic malignancies. Clin. Chem. 2005, 51, 113-118. [CrossRef] [PubMed]

111. Alegre, E.; Fusco, J.P.; Restituto, P.; Salas-Benito, D.; Rodriguez-Ruiz, M.E.; Andueza, M.P.; Pajares, M.J.; Patino-Garcia, A.; Pio, R.; Lozano, M.D.; et al. Total and mutated EGFR quantification in cell-free DNA from non-small cell lung cancer patients detects tumor heterogeneity and presents prognostic value. Tumour Biol. 2016, 37, 13687-13694. [CrossRef] [PubMed]

112. Garzon, M.; Villatoro, S.; Teixido, C.; Mayo, C.; Martinez, A.; de Los Llanos Gil, M.; Viteri, S.; Morales-Espinosa, D.; Rosell, R. KRAS mutations in the circulating free DNA (cfDNA) of non-small cell lung cancer (NSCLC) patients. Transl. Lung Cancer Res. 2016, 5, 511-516. [CrossRef] [PubMed]

113. Nygaard, A.D.; Garm Spindler, K.L.; Pallisgaard, N.; Andersen, R.F.; Jakobsen, A. The prognostic value of KRAS mutated plasma DNA in advanced non-small cell lung cancer. Lung Cancer 2013, 79, 312-317. [CrossRef] [PubMed]

114. Ai, B.; Liu, H.; Huang, Y.; Peng, P. Circulating cell-free DNA as a prognostic and predictive biomarker in non-small cell lung cancer. Oncotarget 2016, 7, 44583-44595. [CrossRef] [PubMed]

115. Yanagita, M.; Redig, A.J.; Paweletz, C.P.; Dahlberg, S.E.; O'Connell, A.; Feeney, N.; Taibi, M.; Boucher, D.; Oxnard, G.R.; Johnson, B.E.; et al. A Prospective Evaluation of Circulating Tumor Cells and Cell-Free DNA in EGFR-Mutant Non-Small Cell Lung Cancer Patients Treated with Erlotinib on a Phase II Trial. Clin. Cancer Res. 2016, 22, 6010-6020. [CrossRef] [PubMed]

116. Imamura, F.; Uchida, J.; Kukita, Y.; Kumagai, T.; Nishino, K.; Inoue, T.; Kimura, M.; Oba, S.; Kato, K. Monitoring of treatment responses and clonal evolution of tumor cells by circulating tumor DNA of heterogeneous mutant EGFR genes in lung cancer. Lung Cancer 2016, 94, 68-73. [CrossRef] [PubMed]

117. Thress, K.S.; Paweletz, C.P.; Felip, E.; Cho, B.C.; Stetson, D.; Dougherty, B.; Lai, Z.; Markovets, A.; Vivancos, A.; Kuang, Y.; et al. Acquired EGFR C797S mutation mediates resistance to AZD9291 in non-small cell lung cancer harboring EGFR T790M. Nat. Med. 2015, 21, 560-562. [CrossRef] [PubMed]

118. Heitzer, E.; Ulz, P.; Geigl, J.B.; Speicher, M.R. Non-invasive detection of genome-wide somatic copy number alterations by liquid biopsies. Mol. Oncol. 2016, 10, 494-502. [CrossRef] [PubMed]

119. Sholl, L.M.; Aisner, D.L.; Allen, T.C.; Beasley, M.B.; Cagle, P.T.; Capelozzi, V.L.; Dacic, S.; Hariri, L.P.; Kerr, K.M.; Lantuejoul, S.; et al. Liquid Biopsy in Lung Cancer: A Perspective From Members of the Pulmonary Pathology Society. Arch. Pathol. Lab. Med. 2016, 140, 825-829. [CrossRef] [PubMed] 